\title{
Rhinos in Thailand
}

\section{Jeffrey A. McNeely and Edward W. Cronin}

Of the two rhinos formerly found in Thailand, the Javan is believed now to be extinct there, although the authors of this survey report that some villagers in southern Thailand insist that the rhinos in their area are Javan. The Sumatran rhino is in desperate straits, with poaching a major threat - not surprisingly when a dead animal can be sold for the equivalent of up to twenty years' wages for a farmer.

The two rhinoceros species in south-east Asia, the Javan (or lesser one-horned) Rhinoceros sondaicus and the Sumatran (or Asian two-horned) Dicerorhinus sumatrensis are now among the rarest mammals in the world. IUCN estimates that there are not more than $\mathbf{5 0}$ Javan and 100-170 Sumatran remaining. Their decline is largely due to human factors beginning at least 50,000 years ago (Martin and Wright).

The first step in preserving these few remaining rhinoceroses is to conduct as accurate a census as possible to determine the size of the problem. This has been done for Java (Hoogerwerf, 1970; Schenkel and Schenkel, 1969), Sumatra (Kurt, 1971), Malaya (Hislop, 1965) and Burma (Milton and Estes, 1963), but not for Thailand, which is well within the historic ranges of both species; few specimens have been collected, and the status and local distribution are poorly reported. To fill the gap, we conducted several short survey expeditions to various parts of the country, examined the relevant literature, and interviewed local villagers, Forestry Department officials, and hill tribe hunters.

On the basis of this information, it appears that there are three primary rhinoceros areas left in Thailand: the Tenasserim Range along the Burmese border; the Malayan border; and Chaiyaphum Province.

Tenasserim The Tenasserim Range forms an interesting zoogeographical boundary, with the Burmese (western) slope covered in tropical rain forest while most of the Thai (eastern) slope is dry deciduous forest. On the Thai side annual dry-season burning by the local people causes a lack of water and green vegetation, and the large mammals spend most of the year on the more lush Burmese side, crossing into Thailand only during the monsoon (May-October). The situation along the Tenasserim is not clear; many prime rhinoceros habitat areas are controlled by Karen hill tribe insurgents (KNDO), making field investigations impossible, and most of the data comes from hunters. A group of Karens from Thailand's Kanchanaburi

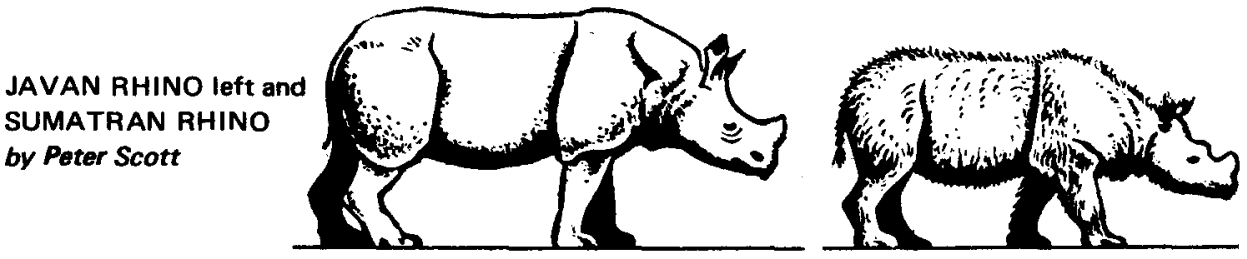


Province reported the following rhinoceroses during the period 1958-1962: 1958, 1 male Javan seen, not killed; 1959, 3 Sumatran seen, one female killed; 1960, a pregnant Javan killed, the foetus dried and sold for US \$25; 1961, 1 Javan and 4 Sumatran seen, none killed; 1962, 1 Sumatran seen, not killed (Boonsong, 1963). Milton and Estes generally confirmed this report, indicating that there were 5-10 Sumatran and perhaps 2 Javan in the Tavoy region of Burma bordering on Kanchanaburi Province ( 2 on map), it seems likely that at least some of these would cross into Thailand during the monsoon.

Malayan border. Hislop (1965) indicated that there were three to six Sumatran rhinos along the Thai border, with one or two in Perak, bordering on Yala Province (4 on map), and two to four in Kedah, bordering on Songkhla ( 5 on map). Some of these might occasionally cross the border into Thailand, but this area is now occupied by insurgents living off the land, so it does not seem likely that the rhino are very secure.

Between the Tenasserim and the Malay border are Krabi and Trang Provinces ( 3 on map), where rhino have been reported by local villagers who insist that they are Javan ('raat' in Thai), not Sumatran ('krasoo'). Both provinces, being sparsely populated and covered with tropical rain forest, are suitable for Javan.

Chaiyaphum Province, in north-east Thailand $\left(16^{\circ} \mathrm{N} ., 101^{\circ} \mathrm{E}\right.$.) (1 on map), is far from any previously reported rhinoceros localities. In 1967 a report that one had been killed in the Petchabun Mountains of Chaiyaphum was greeted with some scepticism, but it was reinforced in 1970 when another rhino was killed in the same area; this time sufficient skin was recovered to enable Thai Forestry Department officials to identify it as Sumatran. In order to have a better insight into the situation at Chaiyaphum, the Association for the Conservation of Wildlife (ACW) in January 1972 sent an expedition to the Phu Kheo Forest Reserve, where the rhino was killed in 1970 and where, according to local hunters, three still exist.

The Forest Reserve, lying roughly between' $16^{\circ} 10^{\prime}-16^{\circ} 30^{\prime} \mathrm{N}$. and $101^{\circ} 25^{\prime}-101^{\circ} 75^{\prime}$ E., is shaped something like Australia, about 55 kilometres from east to west and 36 north to south; the eastern 60 per cent of the Reserve forms a dish-like plateau, with the edges rising from the 300-metre plain to 1100 metres and the plateau centre falling to about 950 metres; the western 40 per cent is in the Petchabun Mountain Range, which continues north through Loei Province to Laos and is very sparsely populated except by Meo hill tribe insurgents.

The only village in the area is Thunghkamung, $17 \mathrm{~km}$ into the Reserve, at the northern edge of the plateau. It is a small village of 30 families, only one of which has been there as long as 10 years; most of the rest are labourers who came to work on the nearby Nam Phrom hydroelectric dam project, quit working, and squatted on governmentowned reserved forest. Although the village economy is based on water buffalo, rice is also grown where the forest has been cleared, and all male villagers hunt in the forest.

Evidence of poaching in the forest was widespread; numerous camp 
fires were found, without exception surrounded by piles of jungle fowl and pheasant feathers. Remains of langur monkey Presbytis pharyrei, macaque monkey Macaca nemestrina and gibbon Hylobates lar were also found. A hunting blind (hide) was discovered in a tree overlooking a flat valley $50-100 \mathrm{~m}$. wide, covered with lush secondary growth.

With one guide we walked up river, reasoning that a rhino, to cross the valley, would have to cross the stream, and it was an ideal situation for tracks. We found tracks of rodents, civets, tigers, bears, elephants, otters, deer, and gaur, and eventually came across one track which appeared to be that of Sumatran rhino. It was $20 \mathrm{~cm}$ wide, well within the normal $18-24 \mathrm{~cm}$ range given by Medway (1969), and well under the 25-35 range for the Javan. The track was at least three weeks old, but the animal appeared to have dug his toes into the bank for a better grip, leaving a relatively clear print for the middle toe, less clear for the side toes. We followed tracks upstream and found other less obvious tracks (though the size was appropriate for Sumatran), a very old wallow, and a few feeding sites, where

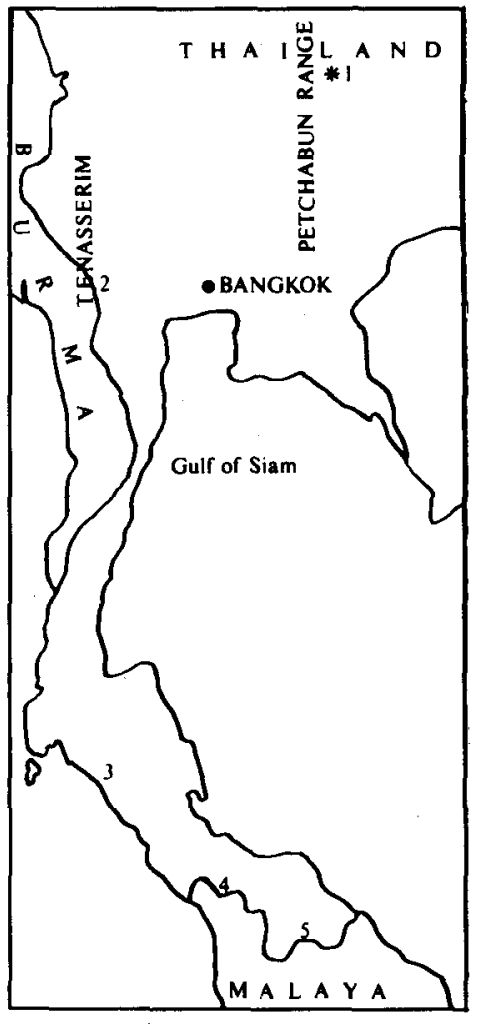
some thin saplings had been twisted in a manner distinctly rhinoceros (Strickland, 1967).

For several days we searched the area, but found no other signs. The local hunters thought that the rhinos had retreated deeper into the forest, and they were afraid to go there because of Meo insurgents. They expected the rhinos to return in May when the rains begin.

The rhinos along the Tenasserim and the Malay border do not represent any addition to the known world rhinoceros population because most of these animals were probably included in earlier censuses. But they are a reminder that rhinoceroses are wide-ranging animals, and that their conservation on the mainland should be considered an international problem, not an internal one. Further, the rhinos living in these areas are part of a political problem, the increasing domination of forested areas by insurgents of various political persuasions, who live off the land, killing large mammals for meat.

Although the situation in Chaiyaphum may be somewhat better, since the rhino population there does not seem to cross any international borders, the area is becoming more densely populated, and there are increasing pressures on forested areas. But, supported by evidence collected by the ACW expedition in January, the Thai Forestry Department recently declared Phu Kheo a game reserve, and a Wildlife Division officer is now stationed there to give the rhinos at least some protection.

Conserving rhinos in Thailand raises a serious economic problem. The remains of a rhino are worth over $\$ 2000$ (10 to 20 years' earnings 
for a Thai farmer), so it is extremely difficult to prevent a villager shooting one if he has a chance. Every part of the rhino has value today (teeth, $\$ 25$ each; dried blood $\$ 75 / \mathrm{kg}$; fresh blood $\$ 65 / \mathrm{kg}$; bone, $\$ 6.50 / \mathrm{kg}$, skin, $\$ 12.50 / \mathrm{kg}$ ), but the horn is the most valuable, with the Bangkok price about $\$ 60$ per ounce. The horn is used for everything from painkiller to easing childbirth, but the most popular use is as an aphrodisiac among elderly Chinese men. Despite the price (or because of it), its sale is widespread; of 25 Chinese medicine shops visited in Bangkok, eight had a complete rhino horn (from which shavings are sold) and several others had fragments. A shop in Nakorn Ratsima, in north-east Thailand, had three complete horns, several fragments, and one complete rostrum skin of sumatrensis, with both horns still attached to the skin. This came from Chaiyaphum, according to the shopowner. Rhino hunting is strictly forbidden in Thailand, with a maximum penalty of one year in jail, a $\$ 500$ fine, or both. Such penalties, however, have never been imposed; the hunter who shot the Sumatran rhino in Chaiyaphum in 1970 was fined $\$ 2.50$ !

With this combination of economic and political pressures, the Thailand rhinos are definitely on their way to extinction, and strong. possibly unpopular, steps are necessary. These should include:

An absolute ban on the sale or possession of any rhino parts; Enforcement of the game laws, with sufficient personnel stationed at the Phu Kheo Game Reserve;

Expert study of the Chaiyaphum population, with the possibility of trying to capture them for removal to a more secure area.

\section{Acknowledgments}

The writers are grateful to Dr. Boonsong Lekagul for his guidance and support; Mr. Pong Leng-Ee, Head of the Wildlife Division of the Thai Forestry Department; and Dr Fred Kurt for his valuable comments.

\section{REFERENCES}

BOONSONG LEKAGUL 1963. Report on the Javan and Sumatran Rhinos on the Thai-Burmese Border. Conservation News. Association for the Conservation of Wildlife. Bangkok.

HISLOP, J.A. 1965. Rhinoceros and Seladang - Malaya's Vanishing Species. Conservation in Tropical South-east Asia. I.U.C.N. Morges.

HOOGERWERF, A. 1970. Udjung Kulon; The Land of the Last Javan Rhinoceros. E.J. Brill. Leiden.

KURT, F. 1971. Report on Gunung Loeser Reserve. Ann. Report of World Wildlife Fund. Morges.

MARTIN, P.S. and H.E. WRIGHT 1967. Pleistocene Extinctions. Yale U. Press. New Haven.

MEDWAY, Lord 1969. The Mammals of Malaya. Oxford U. Press. Kuala Lumpur.

MILTON, O. and R.D. ESTES 1963. Burma Wildlife Survey. Special Pub. 16, American Comm.Int.Wild Life Protection. New York.

SCHENKEL, R. and L. SCHENKEL-HULLIGER 1969. The Javan Rhinoceros in Udjung Kulon Nature Reserve. Acta Tropica.

STRICKLAND, D. 1967 Ecology of the Rhinoceros in Malaya. Malayan Nature Journal Vol. 20, No. 1. 